\title{
Gross Anatomical, Histological and Histochemical Studies on the Postnatal Development of the Prostate Gland of Gaddi Goat
}

\author{
Estudios Anatómicos Macroscópicos, Histológicos e Histoquímicos sobre el \\ Desarrollo Postnatal de la Glándula Prostática de la Cabra Gaddi
}

\author{
Archana Pathak; R. S. Katiyar; D. N. Sharma; M. M. Farooqui \& Ajay Prakash
}

PATHAK, A.; KATIYAR, R. S.; SHARMA, D. N.; FAROOQUI, M. M. \& PRAKASH, A. Gross anatomical, histological and histochemical studies on the postnatal development of the prostate gland of Gaddi goat. Int. J. Morphol., 30(2):731-739, 2012.

SUMMARY: The study was conducted on the prostate gland of Gaddi goat from one day old to more than five years of age divided into three groups viz; Prepubertal (1 day old to < 18 months of age), Pubertal (18 months to < 5 yrs of age) and Postpubertal ( > $5 \mathrm{yrs}$ of age). The prostate comprised of corpus prostatae, a band like structure close to the junction of vesicular gland with the urethra, and the pars disseminate which extended in urethra well from its origin to the point of duct of bulbourethral gland. Microscopically, the corpus prostatae comprised of two compact glandular masses lying one over the other, dorsally over the origin of pelvic urethra covered by a thick fibro-reticular capsule. The gland composed of end pieces (luminated and non-luminated acini) and ducts arranged in lobulated fashion. The thickness of inter and intralobular connective tissue decreased with increased age at the expense of the growth of paraenchyma. With age the luminated secretory end pieces increased, while the non-luminatedend pieces decreased in the lobules of the gland. Glandular parenchyma were rich in mucous components by 6 month age serous and mucous components became almost equal and at 12 month age majority of the secretory end pieces turned in to serous type. The excretory ducts which were lined by stratified cuboidal epithelium in one day old kids changed to transitional epithelium in late prepubertal and pubertal animals. The glandular elements were PAS and Best's carmine reactive while interstitial connective tissue was non reactive. Mild alkaline phosphatase reaction was evident in the interstitial connective tissue cells. A strong acid phosphatase reaction was evident in the endothelium. BPB reaction for protein was moderate to intense. Ducts and acini were PAS and Alcian Blue reactive. The reaction for glycogen and AMPS contents in the gland increased with age. It was very intense in the pubertal animals. Moderate DNA activity, mild to moderate alkaline and acid phosphatases in the glandular acini and ductal epithelium revealed functionally active secretory glands particularly in the pubertal animals.

KEY WORDS: Prostate gland; Postanatal; Corpus prostatae; Pars disseminate; Goat.

\section{INTRODUCTION}

Gaddi goats are the migratory goats reared in the temperate zone of Himachal Pradesh and Jammu Kashmir. These are mostly reared by the tribals for the milk, meat, hide hair etc.; thus forming the backbone of the economy of these tribals of North-Western Himalayan region of the country.

Prostate gland has a major contribution in the seminal fluid which plays important role in male fertility. Its functional significance lies in neutralizing the seminal plasma and to initiate active movement of the ejaculated spermatozoa (Eurell \& Frappier, 2007; Hafeez 1987). Histological and histochemical studies have been made on the prostate gland of cattle (Stallcup, 1969), buffalo (Sudhakar et al., 1984, 1985), camel (Ali et al., 1976) and ram (Roy et al., 1985). Keeping in view the functional significance of the gland and nonavailability of literature on the subject in Gaddi goats, the present work has been carried out. The paper records the sequential account of structural changes in the prostate gland during various stages in postnatal life.

\section{MATERIAL AND METHOD}

Complete male genetalia were dissected out from 30 male Gaddi goats divided into three groups of 10 animals in each viz; Prepubertal (1 day old to < 18 months of age), Pubertal (18 months to $<5$ yrs of age) and Postpubertal (> 5 yrs of age). Besides these, five samples of one day old kids were collected from the clinical complex. After detailed gross morphological examinations, thin pieces of tissues were collected from the proximal, middle and distal part of the 
pelvic urethra and fixed in $10 \%$ neutral buffered formalin, formal acetic alcohol (FAA) and cold acetone. The fixed tissues were processed through routine alcohol-benzene schedule, infiltrated and embedded in paraffin $(60-620 \mathrm{C}$ melting point). The cold acetone fixed tissues were embedded in paraffin of low melting point (52-540C) for carbohydrate and enzyme study. Thin paraffin sections $(5 \mu)$ were cut and stained with Haematoxylin and Eosin for routine fibrocellular architecture, Van Gieson's stain for collagen, Gomori's reticulin method for reticular fibers and Weigert's resorcin fuchsin and Orcein stains for elastic fibers (Luna, 1968), PAS with and without saliva as well as diastase (Davenport, 1960) for polysaccheridesand glycogen, Alcian blue at $\mathrm{pH} 2.5$ (Luna) for acid mucopolysaccherides (AMPS), Azodye method for alkaline and acid phosphatase (Barka \& Anderson 1963), Sudan Black-B in propylene glycol (Luna) for lipids, Bromophenol- blue method (Pearse, 1968) for protein and Feulgen's reaction (Davenport) for DNA demonstration. Micrometrical measurements were recorded with the help of calibrated ocular micrometer. Data were subjected to standard statistical analysis for interpretation.

\section{RESULTS}

Gross Anatomy. Prostate glands in goats mostly comprised of pars disseminata. But in some Gaddi goats the existence of the corpus prostatae was also confirmed. In one- day old Gaddi kids, a white coloured band of tissue was observed below a fibrous cord which joined the two vesicular glands at the junction of urinary bladder with pelvic urethra. Not very infrequently, this type of tissue was also observed in the samples of the pre-pubertal and pubertal goats.

The pars disseminata of the gland occupied the entire wall of the pelvic urethra. The gland occurred in the urethra from its junction with the urinary bladder to the level of the ischial arch. It was surrounded by the urethral muscle which was thin dorsally, increased in thickness laterally and became thin ventrally. In the cranial portion of the pelvic urethra, the glandular tissue was mostly present in the dorsal wall only. It was relatively sparse in the lateral and ventral walls of the pelvic urethra. In the middle portion of the pelvic urethra, the distribution of the gland (in cross section) was almost uniform encircled the whole pelvic urethra except in $1-2 \%$ of the very small ventral part. In the caudal segments of the pelvic urethra, the distribution of glandular elements was limited to the half of the pelvic urethra (in cross section).

In pubertal and postpubertal animals, the corpus prostatae was frequently observed in various samples as a distinct white colour band below the cord joining the two vesicular glands. In postpubertal animals, it was approximately $0.56 \mathrm{~cm}$ in height.

Microscopic Anatomy. The Corpus prostatae of one day old Gaddi goat kids appeared as the two (one lying above the other, dorsal and ventral) small, compact glandular masses enclosed in a thick fibrous capsule, laid along the dorsal wall of the pelvic urethra (Figs. 1 and 2). These glands were not covered by the urethral muscle dorsally. The urethral muscle started only along its lateral aspect. These glandular components were well demarcated from the pars disseminate of the prostate by means of the fibrous capsule (Fig. 2). These two bands of the corpus prostatae laid horizontally in the dorsal wall of the pelvic urethra. The pars disseminate, in contrast filled up the major component of the urethral wall reaching almost to the lumen of the urethra.

The corpus prostatae of one day old Gaddi kid was covered by a $63.14 \mu \mathrm{m}$ thick fibrous capsule. A number of trabeculae approx. $6.58 \mu \mathrm{m}$ thick arose from the capsule and divide the glandular tissue into lobes and lobules. The thickness of interlobular and intralobular connective tissue measured $9.08 \mu \mathrm{m}$ and $2.95 \mu \mathrm{m}$, respectively. The capsule comprised of collagen and reticular connective tissue fibers and smooth muscles. In one day old kids, mild to rich collagen concentration was observed in the capsular and interlobular connective tissue (Figs. 1 and 2). The collagen also occurred in and extended along the wall of blood vessels. Reticular fibers were seen only sparsely in the stroma. The capsular thickness and interlobular connective tissue decreased with increased in age. The average capsular thickness in prepubertal animals measured $47.60 \mu \mathrm{m}$. the interlobular and intralobular connective tissue thickness measured 7.72 and $2.27 \mu \mathrm{m}$ respectively

The placement of corpus prostatae in pubertal and postpubertal Gaddi goats was same as observed in the prepubertal Gaddi goats. It was well separated and demarcated from the pars disseminate of the prostate by means of fibrous capsule. The thickness of capsule decreased in pubertal and further in postpubertal group however, the amount of connective tissue in the trabeculae containing smooth muscle, collagenic and reticular fibers increased. The interlobular connective tissue also reduced with the advancement in age from pubertal to postpubertal animals in the thickness in the pubertal animals. In postpubertal animals, the interlobular and intralobular connective tissue was sparse and scattered. The average capsular thickness in pubertal and postpubertal animals measured 35.66 and $25.87 \mu \mathrm{m}$, respectively (Table I).

Glandular tissue. In one day old kids, the glandular tissue was represented by luminated as well as non-luminated secretory end pieces and ducts (Figs. 1 and 2). The luminated 


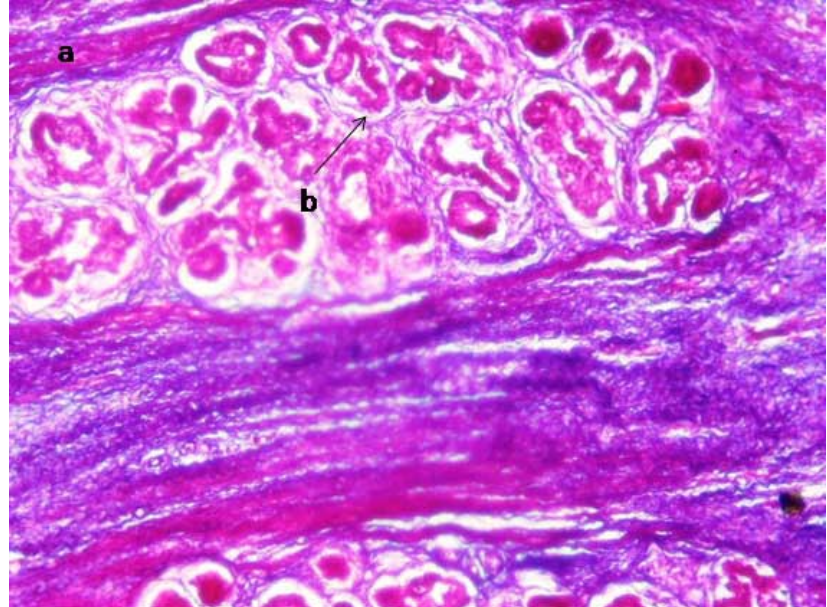

Fig. 1. Photomicrograph of prostate gland of one day old Gaddi kid showing corpus prostatae showing capsule (a) and intralobular connective tissue (b). Masson's trichrome stain X 100.

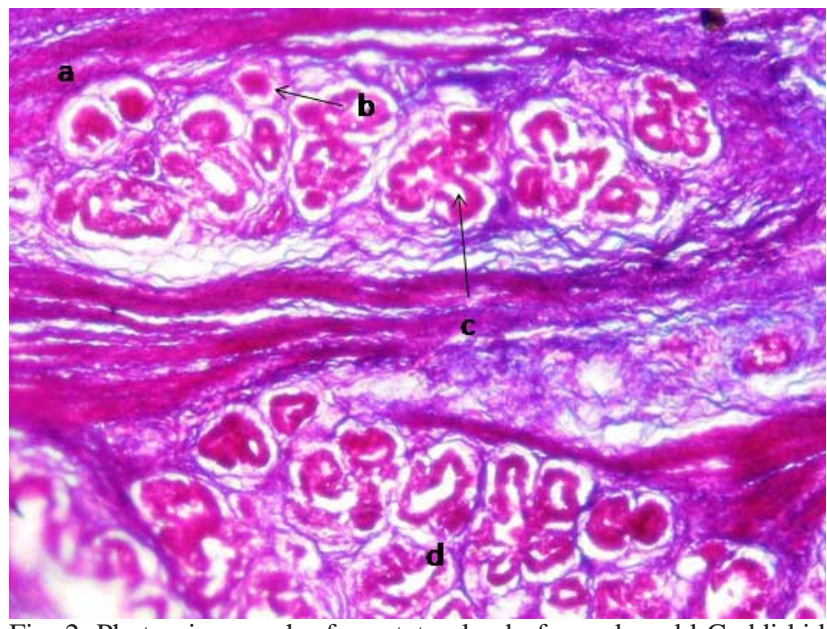

Fig. 2. Photomicrograph of prostate gland of one day old Gaddi kid showing corpus prostatae having its own capsule (a), luminated (b) and non-luminated acini (c), separated from the pars disseminate (d). Masson's trichrome stain X 100.

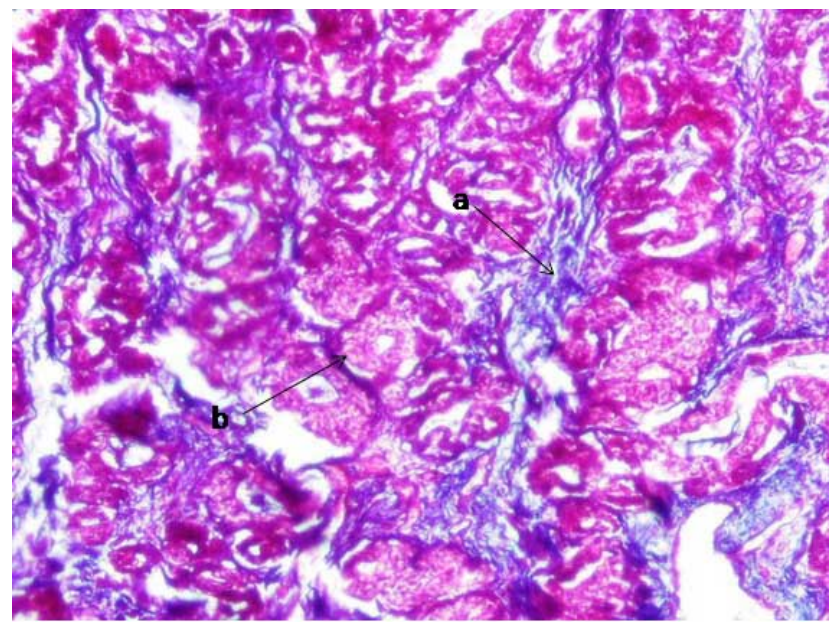

Fig. 3. Photomicrograph of prostate gland of one day old Gaddi kid showing collagen distributions in the interlobular (a) and periacinar connective tissue (b) of pars disseminata. Masson's trichrome X 100.

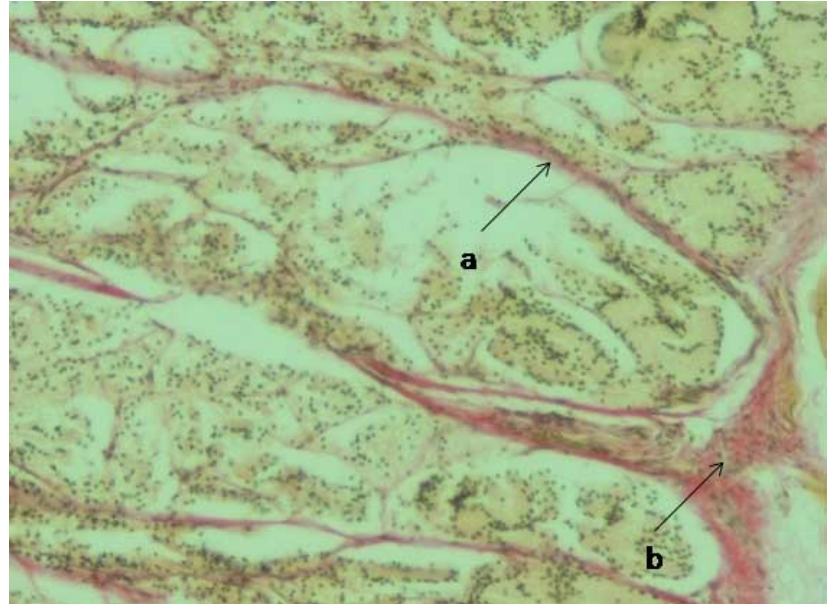

Fig. 4. Photomicrograph of prostate gland of prepubertal Gaddi goat showing septae (a) formation by the collagen fibers in the interlobular connective tissue originating right from the capsule. VanGieson,s stain X100.

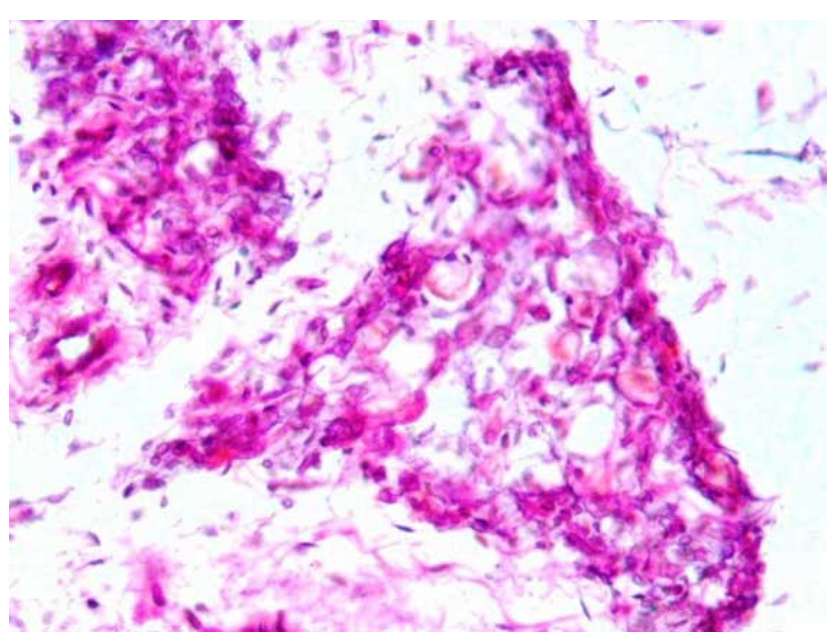

Fig. 5. An encapsulated nerve ending in the connective tissue (a). PAS X 100 .

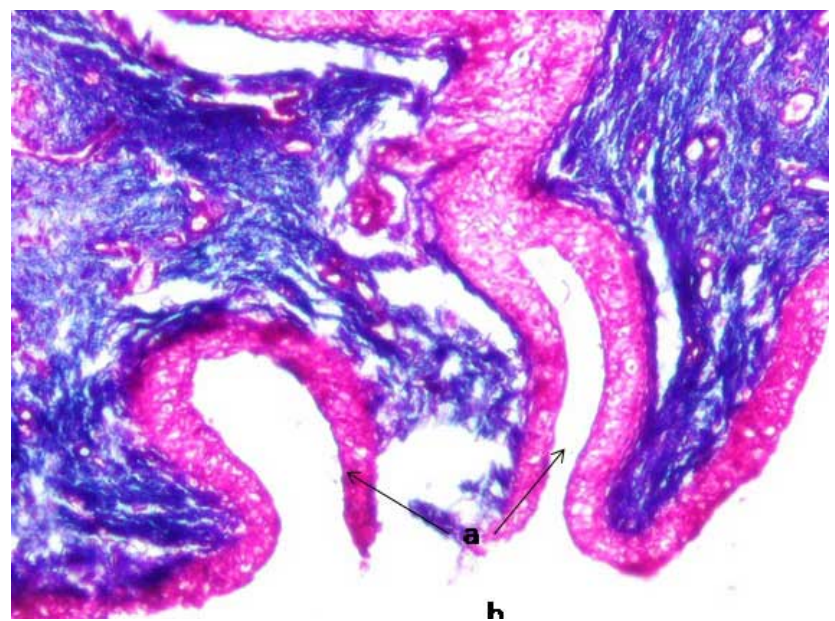

Fig. 6. Two prostatic ducts (a) lined by the stratified columnar epithelium and opening into the urethral lumen (b). Masson's trichrome X 100 . 
secretory end pieces measured on an average $40.40 \mu \mathrm{m}$ in diameter. They were lined by simple columnar to pyramidal shaped epithelium, which rested on a distinct basement membrane. The mean height and width of the epithelial cells measured 13.62 and $4.54 \mu \mathrm{m}$, respectively. The cytoplasm of these cells was intensely eosinophilic. The centrally placed rounded nuclei measured on an average $4.42 \mu \mathrm{m}$ in diameter. The average diameter of the non-luminated secretory end pieces were $33.67 \mu \mathrm{m}$. The mean height and width of the lining simple columnar epithelial cells were 13.24 and 4.54 $\mu \mathrm{m}$, respectively. In these cells also, the rounded nuclei (4.54 $\mu \mathrm{m}$, diameter) were placed in the center. The diameter of the ducts of the corpus prostatae measured $40.86 \mu \mathrm{m}$. These were lined by stratified cuboidal epithelium with rounded nuclei resembling those of secretory end pieces. The average height of the epithelium was $12.64 \mu \mathrm{m}$ and their nuclei measured on an average $4.54 \mu \mathrm{m}$ in diameter. In pre-pubertal animals the average diameter of acini measured $44.98 \mu \mathrm{m}$ and the height of their epithelium was $12.89 \mu \mathrm{m}$ (Table I).

The secretory end pieces increased in number in pubertal Gaddi goats as compared to prepubertal animals. The luminated acini dominated over the non-luminated acini. The average diameter of acini was $52.70 \mu \mathrm{m}$. These were lined by $15.20 \mu \mathrm{m}$ high simple columnar epithelial cells (Table I). Their nuclei were either oval or rounded. The rounded nuclei were $3.98 \mu \mathrm{m}$ in diameter and the oval nuclei were $4.54 \mu \mathrm{m}$ in height and $3.85 \mu \mathrm{m}$ in width.

The number of alveoli further increased in postpubertal animals, yet the alveolar diameter and epithelial height of alveoli did not change much over the preceding group of animals. The average diameter of acini and the height of epithelial cells are summarized in Table I.

The Pars disseminate. The disseminate portion of the prostate gland occurred throughout the length of the pelvic urethra. It was enclosed by the connective tissue capsule composed of collagenic, elastic, reticular fibers and smooth muscle cells (Figs. 3 and 4). In one day old Gaddi kids, the capsule was thin dorsally; however it increased in thickness laterally. Again it reduced in thickness in its ventral part, but remains thicker than the dorsal portion. Similar pattern was observed in the capsule of the pars disseminate of the later stages of pre-pubertal animals. The average capsular thickness in one day old kids was $78.40 \mu \mathrm{m}$. In pre-pubertal animals its average thickness was $103.39 \mu \mathrm{m}$ (Table I).

A layer of skeletal muscle (M. uretheralis) surrounded by loose connective tissue rich in collagenic and reticular fibers along with blood vessels enveloped the gland capsule. Several autonomic ganglia, encapsulated nerve endings (lamellated corpuscles and nerve trunks were observed in

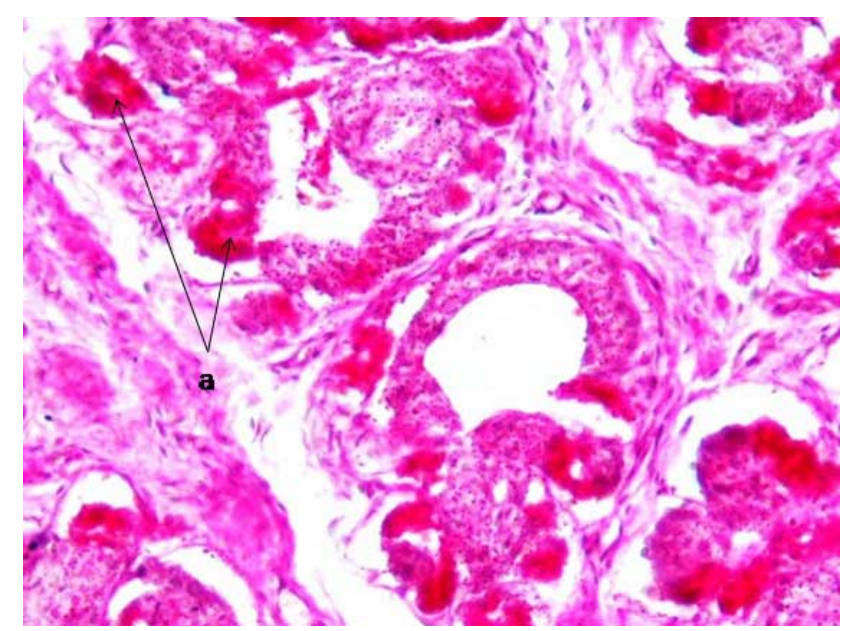

Fig. 7. PAS reaction in the lining epithelium of acini (a). PAS X 100.

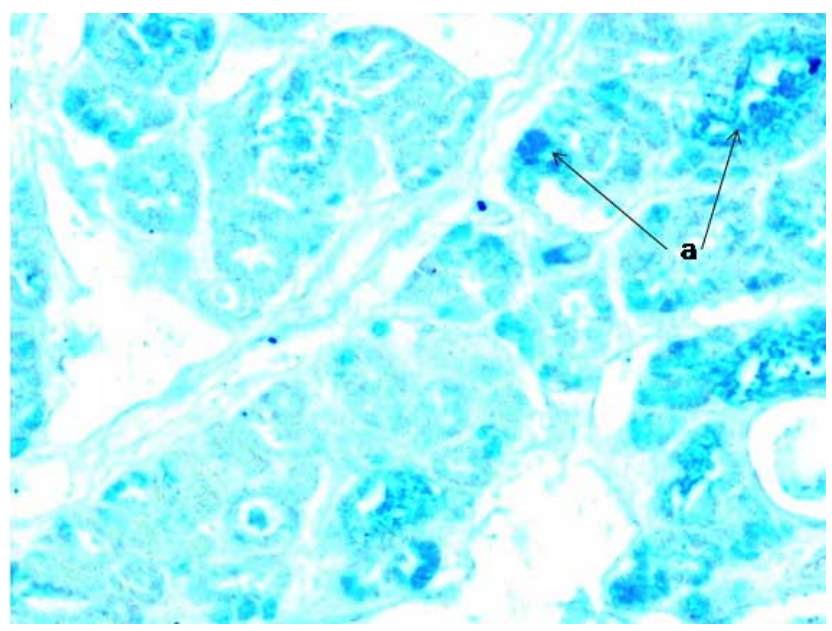

Fig. 8. Mixed type of AMPS reaction in the acinar cells (a) with in the lobules. Alcian Blue X 100.

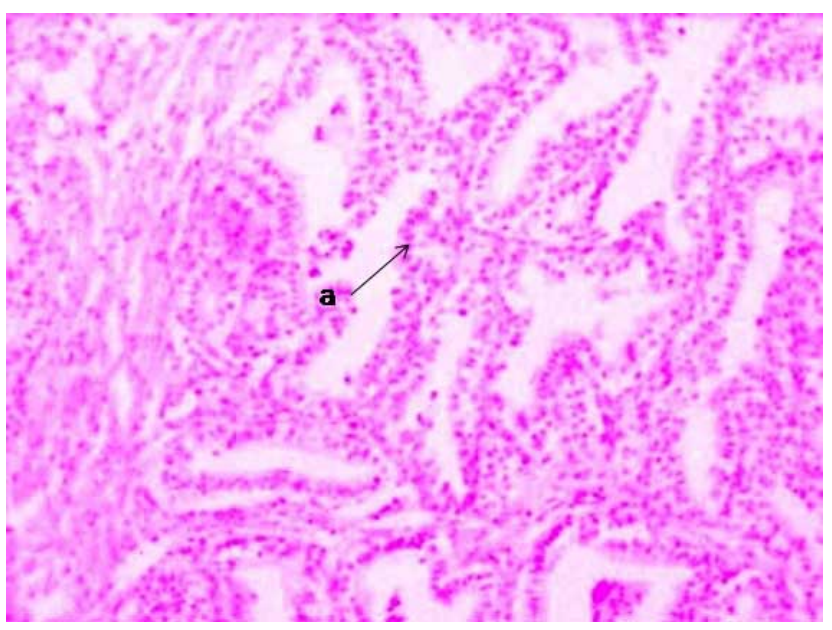

Fig. 9. Presence of DNA in the nuclei of acinar cells (a). Feulgen's reaction X 100.

the connective tissue sheath (Fig. 5). The connective tissue trabeculae extending from the capsule descended into the 
parenchyma of gland forming interlobular connective tissue and divided the gland into smaller lobules. The trabeculae on an average were $66.64 \mu \mathrm{m}$ thick in one day old kids. Further, interlobular and intralobular connective tissue thickness measured $58.80 \mu \mathrm{m}$ and $4.19 \mu \mathrm{m}$, respectively. Histologically, they were similar in structure as those of the corpus prostaticus. The thickness of trabeculae increased but interlobular and intralobular connective tissue decreased with increase in age (Table I). The average thickness of trabeculae, interlobular and intralobular connective tissue in pre-pubertal Gaddi goats was 52.92, 37.43 and $4.54 \mu \mathrm{m}$, respectively.

In pubertal and postpubertal gaddi goats the capsular thickness was 202.66 and $331.24 \mu \mathrm{m}$ respectively (Table I). The amount of densely woven collagen fibers increased in the pubertal animals. The thickness of uretheralis muscle also increased with increase in age. The trabeculae increased in thickness, whereas, the interlobular, intralobular connective tissue decreased with the advancement of age (Table I).

Glandular Tissue. The luminated and non-luminated secretory end pieces of pars disseminate were distributed within the wall of the pelvic urethra. In one day old kids, the average diameter of the luminated secretory end pieces was $43.69 \mu \mathrm{m}$ whereas, that of non-luminated secretory end pieces was $30.19 \mu \mathrm{m}$. Both types of secretory end pieces were lined by single row of columnar or pyramidal shaped cells. The average height of the epithelium in both types of secretory end pieces was $12.93 \mu \mathrm{m}$. The average height and width of the nucleus in luminated end pieces measured 3.85 and $4.19 \mu \mathrm{m}$, respectively. The same parameters in nonluminated secretory end pieces were 4.08 and $4.31 \mu \mathrm{m}$, respectively.

With the advancement of age, the number of luminated secretory end pieces increased over the nonluminated secretory end pieces. In pre-pubertal goats, the mean diameter of luminated secretory end pieces was 36.93 $\mu \mathrm{m}$ whereas, those of non-luminated secretory end pieces was $26.87 \mu \mathrm{m}$ (Table I). Both types of secretory end pieces were lined by simple columnar or pseudostratified columnar epithelium. The mean cell height and width measured 11.03 and $4.54 \mu \mathrm{m}$ respectively in luminated secretory end pieces. The average height and width of the nucleus was 4.19 and $4.09 \mu \mathrm{m}$, respectively. The mean height and width of the cells of the non-luminated secretory end pieces were 11.80 and $4.31 \mu \mathrm{m}$, respectively and their nucleus was $7.73 \mu \mathrm{m}$ in height and $3.97 \mu \mathrm{m}$ in width. The glandular alveoli were mainly mucous type with only a few serous ones placed only in the peripheral part of the pars disseminate prostate in one day old kids. With the advancement of age, the number of serous glands increased. At 6 months of age, the alveoli of both serous and mucous type constituted the secretory parenchyma of the gland. Beyond 12 months of age, the serous alveoli were predominantly present in the glandular parenchyma.

Table I. Micrometrical parameters of the various components of the prostate gland in Gaddi goats at various age groups. Values of ten means of ten animals. Figures in the parenthesis indicate the range. a, b, c, ...... shows the significant difference between the groups. *Only luminated end pieces were considered for micrometry; although a few non luminated end pieces were observed in day old kids' corpus prostatae.

\begin{tabular}{|c|c|c|c|c|c|}
\hline s. $\mathbf{n}$ & \multicolumn{2}{|c|}{ Parameters } & Pre-pubertal & Pubertal & Post-pubertal \\
\hline 1 & \multicolumn{2}{|c|}{ Thickness of capsule } & $103.39 \mathrm{a} \pm 6.02$ & $202.66^{\mathrm{b}} \pm 9.43$ & $331.24^{\mathrm{c} \pm} 14.16$ \\
\hline & \multirow{3}{*}{\multicolumn{2}{|c|}{ Trabecular thickness }} & $(78.4-130.34)$ & $(164.64-242.06)$ & $(262.64-396.90)$ \\
\hline \multirow[t]{2}{*}{2} & & & $52.92 \mathrm{a} \pm 2.29$ & $81.24^{\mathrm{b} \pm} 1.79$ & $106.23 c \pm 3.23$ \\
\hline & & & $(45.08-66.64)$ & $(72.52-89.18)$ & $(190.16-118.58)$ \\
\hline \multirow[t]{2}{*}{3} & \multirow{2}{*}{\multicolumn{2}{|c|}{ Interlobular connective tissue thickness }} & $37.44 \mathrm{c} \pm 2.98$ & $18.52^{\mathrm{b} \pm} 1.49$ & $6.08^{\mathrm{a} \pm}-0.62$ \\
\hline & & & $(27.44-58.8)$ & $(11.76-26.46)$ & $(13.41-8.85)$ \\
\hline \multirow[t]{6}{*}{4} & \multirow{6}{*}{$\begin{array}{l}\text { Secretory end } \\
\text { pieces of pars } \\
\text { disseminata }\end{array}$} & Diameter of luminated & $36.93 \mathrm{a} \pm 1.02$ & $40.86^{\mathrm{b} \pm}-0.91$ & $46.69 \mathrm{c} \pm 1.65$ \\
\hline & & acini & $(33.59-43.69)$ & $(36.88-45.85)$ & $(41.31-55.38)$ \\
\hline & & Diameter of non-luminated & $26.87 \mathrm{a} \pm 0.77$ & $35.23^{\mathrm{b} \pm}-0.93$ & $42.77 \mathrm{c} \pm 0.84$ \\
\hline & & acini & $(23.84-31.32)$ & $(32.00-40.63)$ & $(39.95-48.35)$ \\
\hline & & Epithelial height & $11.03 \mathrm{a} \pm 0.33$ & $12.92^{\mathrm{b} \pm} 0.18$ & $14.75 \mathrm{c} \pm 0.23$ \\
\hline & & & $(9.53-12.93)$ & $(11.80-13.62)$ & $(13.62-15.66)$ \\
\hline \multirow[t]{4}{*}{5} & \multirow{4}{*}{$\begin{array}{l}\text { Duct of pars } \\
\text { disseminata }\end{array}$} & Diameter of duct & $32.62 \mathrm{a} \pm 1.05$ & $44.22^{\mathrm{b} \pm 0.60}$ & $46.44 \mathrm{c} \pm 0.36$ \\
\hline & & & $(28.68-38.17)$ & $(40.41-46.31)$ & $(44.72-48.35)$ \\
\hline & & Epithelial height & $11.84 \mathrm{a} \pm 0.11$ & $12.12^{\mathrm{b} \pm 0.08}$ & $12.55 \mathrm{c} \pm 0.03$ \\
\hline & & & $(11.35-12.26)$ & $(11.08-12.49)$ & $(12.48-12.71$ \\
\hline \multirow[t]{6}{*}{6} & \multirow{2}{*}{\multicolumn{2}{|c|}{ Capsular thickness of corpus prostatae }} & $47.60 c \pm 2.29$ & $35.66^{\mathrm{b} \pm} 1.03$ & $25.87 \pm \pm 0.78$ \\
\hline & & & $(40.63-66.28)$ & $(30.42-40.63)$ & $(22.01-29.73)$ \\
\hline & \multirow{2}{*}{\multicolumn{2}{|c|}{ Diameter of acini }} & $44.98^{\mathrm{a}} \pm_{1.31^{*}}$ & $52.70^{\mathrm{b} \pm} \pm 0.63$ & $58.65 \mathrm{c} \pm 0.42$ \\
\hline & & & $(39.49-49.25)$ & $(39.49-49.25)$ & $(56.97-61.06)$ \\
\hline & \multirow{2}{*}{\multicolumn{2}{|c|}{ Epithelial height }} & $12.89 a \pm 0.28$ & $15.20^{\mathrm{b} \pm} 0.39$ & $18.06 \mathrm{c} \pm 0.18$ \\
\hline & & & $(11.57-13.84)$ & $(13.62-17.02)$ & $(17.02-19.06)$ \\
\hline
\end{tabular}




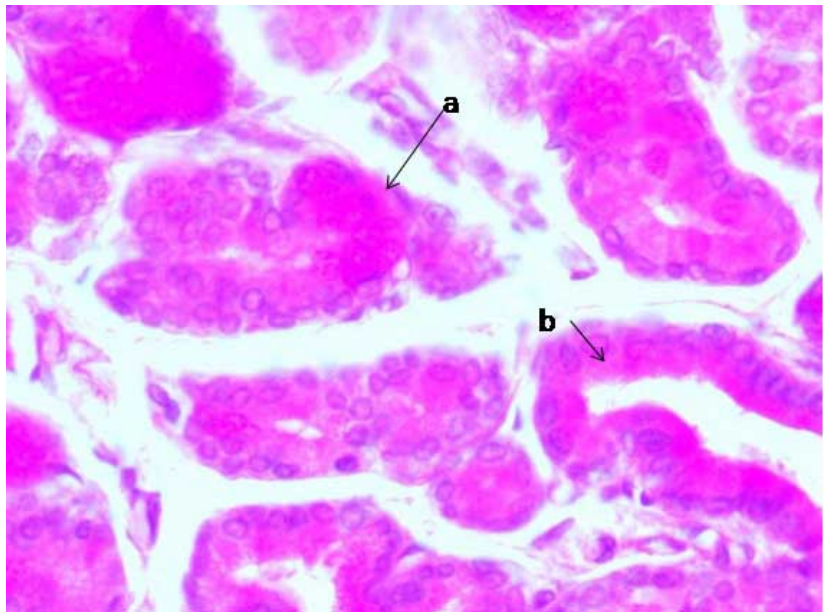

Fig. 10. Foamy type of strongly PAS reaction in the acini (a) and duct (b). PAS X 100.

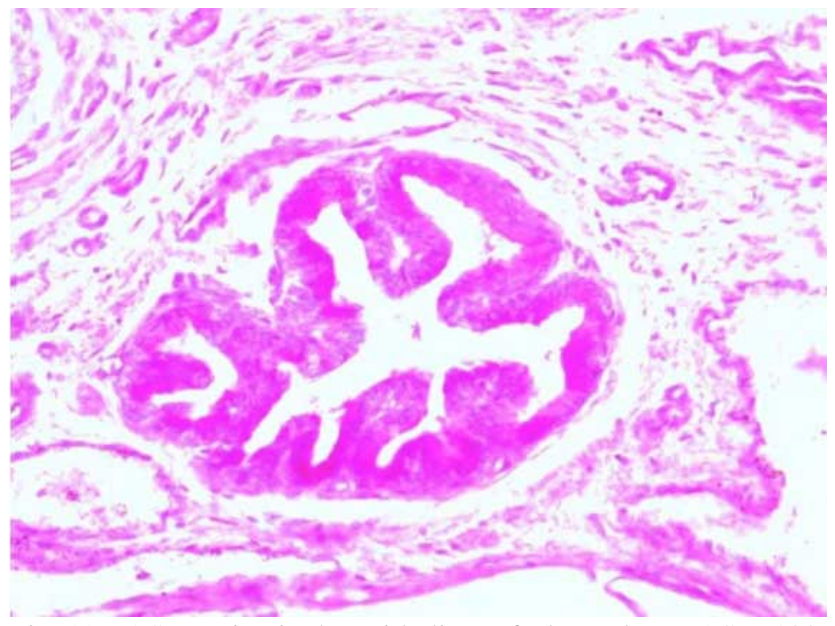

Fig. 11. PAS reaction in the epithelium of a large duct. PAS X 100.

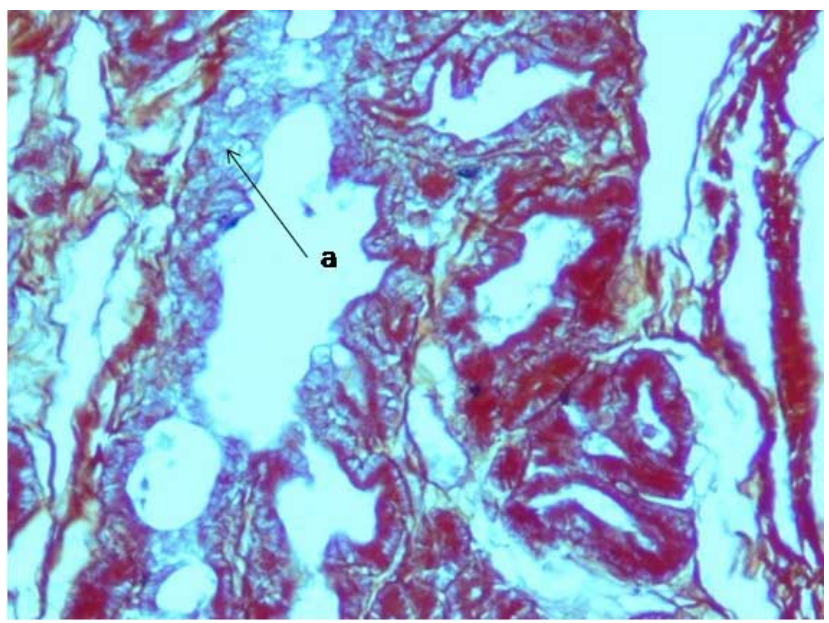

Fig. 12. Presence of protein in the epithelium of the interlobular duct (a). Bromophenol Blue reaction X100.

In pubertal animals, the luminated acini predominated in the pars disseminate. Further the serous alveoli dominated

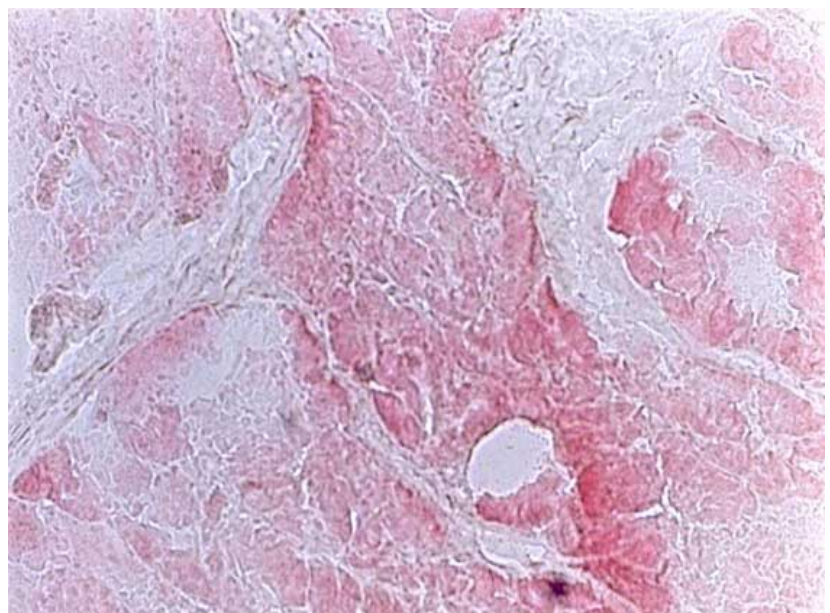

Fig. 13. Moderate acid phosphatase activity in the parenchyma of the pars disseminata. Azodye method. X 200.

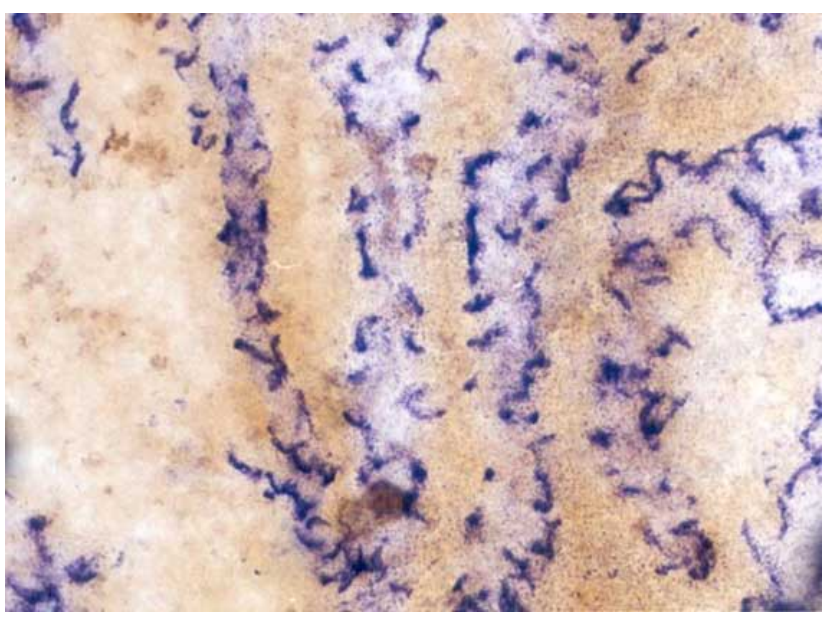

Fig. 14. Intense alkaline phosphatase activity in the glandular epithelium, cistern and ducts. Azodye method. X 200.

the parenchyma. These differed in shapes and sizes in different parts of the gland. On an average the diameter of luminated secretory end piece was $40.86 \mu \mathrm{m}$ and nonluminated secretory end piece was $35.23 \mu \mathrm{m}$. The height of the epithelium was $11.03 \mu \mathrm{m}$ (Table I).

In post-pubertal animals the histological picture of the gland was same as observed in the previous group. Other micrometrical parameters are summarized in Table I.

Ducts. Each lobule of the pars disseminata contained luminated ducts which opened into the pelvic urethra. The mean diameter of these ducts was $28.68 \mu \mathrm{m}$ in one day old Gaddi kid. These ducts were lined by stratified cuboidal to transitional epithelium of an average $11.35 \mu \mathrm{m}$ height and $8.96 \mu \mathrm{m}$ width. The height and width of the nuclei was 4.31 $\mu \mathrm{m}$ and $4.42 \mu \mathrm{m}$, respectively. The cytoplasm of the epithelial cells was homogeneously eosinophilic. A few large clear 
cells were also noticed at places in the epithelium of the ducts. In pre-pubertal animals the ducts were lined by multilayered epithelium with distinct basement membrane formed of thick reticular fibers (Fig. 6). The average diameter of the duct in pre-pubertal Gaddi goats was $32.62 \mu \mathrm{m}$. The average height and width of the epithelium was $11.84 \mu \mathrm{m}$ and $4.19 \mu \mathrm{m}$, respectively. The average nuclear height and width was $3.86 \mu \mathrm{m}$ and $3.52 \mu \mathrm{m}$, respectively.

The average diameter of duct in pubertal and postpubertal Gaddi goats measured 44.22, and $46.44 \mu \mathrm{m}$, respectively. These were lined by 12.12 and $12.55 \mu \mathrm{m}$ high columnar epithelium respectively (Table I). Towards the lumen of urethra these were lined by pseudostratified columnar epithelium.

Histochemistry. The reticulin of the capsule and urethral muscle surrounding the corpus prostatae and pars disseminate showed PAS positive granules. A moderate to strong saliva resistant PAS positive reaction was noticed in the cytoplasm of epithelial cells of ducts and alveoli (Fig. 7). These epithelial cells had distinct cell boundaries with PAS positive basement membrane. PAS positive granules of various size and forms were seen in the cells of duct and acini of prostate gland. The cytoplasm of the cells lining the duct and alveoli showed moderate to intense positive AMPS reaction (Fig. 8). The intensity of PAS and Alcian blue staining reaction increased with age. The membrane of the nuclei and apical border of the epithelial cells lining the ducts and glandular alveoli exhibited a mild to moderate activity for alkaline and acid phosphatase. A mild alkaline phosphatase reaction was evident in the nuclear membrane of the interstitial cells. A strong activity for acid phosphatase was noticed in the endothelium of blood vessels. Bromophenol blue reaction for protein was moderate to intense in the acinar cells and strongly positive in the skeletal muscle, connective tissue of lamina propria and terminal duct of the prostate gland.

The bound and acidic lipids were invariably noticed in the cells of the glandular parenchyma. A moderate Feulgen reaction was seen in the nuclei of acinar cells and ductular epithelium (Fig. 9).

In pubertal animals, the cytoplasm of all the secretory end pieces was strongly PAS reactive. PAS positive granules occurred in the cells lining the duct and acini (Figs. 10 and 11). Alcian blue reaction was strongly positive in certain lobules whereas, in other lobules it could not be seen. Intralobular and interlobular ducts showed very strong Alcian blue reaction at the luminal border. Ductal epithelium was Bromophenol Blue reactive (Fig. 12). The acid phosphatase reaction was moderate, whereas the alkaline phosphatase reaction was intensely represented in the ductal epithelium (Figs. 13 and 14). Lipid was moderately represented in granular form.

Histochemical picture in post-pubertal group was almost similar to those as recorded in the pubertal group of animals.

\section{DISCUSSION}

In the present study a white band like corpus prostatae was located at the origin of pelvic urethra from the bladder in the neonatal kids. However, in text book descriptions, the corpus prostaticus does not occur in the small ruminants (Sisson, 1975; Dellmann \& Wrobel, 1976). Further Kundu (1980) and Gupta \& Singh (1982) and Gupta (1989) described only the Pars disseminate in the goats. The same was also located more distinctly in similar location on the urethra of late pre-pubertal, pubertal and post-pubertal bucks. In the later group of animals it was more clearly demarcated as a constricted white band of glandular tissue. Roy et al. also observed a small compact glandular mass embedded in the urethral muscle of ram and named it as corpus prostatae.

The pars disseminata lay in the urethral wall from the level of union of vesicular gland to the union of bulbourethral gland in the pelvic urethra as also reported by Aitken (1955). Initially it lay in the dorsal wall, and then it extended on either side of the urethra to finally surround it from all sides except in about $2 \%$ of the ventral wall. This was in conformity with the description of Sisson and Dellmann \& Wrobel who described it to occur all around the urethra in the propria of small ruminants. Gupta \& Singh and Gupta located it mostly in the ventral and lateral walls with only a few small lobules in the dorsal wall of urethra of male goats.

Microscopically, the corpus prostaticus, when present, lay as horizontally placed glandular mass surrounded by its own separate thin fibrous capsule and distinctly uncovered bythe urethral muscle. They were generally two and lay one over another, separated from the disseminate component along the dorsal wall of the urethra of the gland. The fibro reticular capsule of the gland also contained abundant smooth muscle cells. Its thickness reduced with age. The parenchyma was divided by connective tissue trabeculae extending from the capsule and comprised luminated and non-luminated secretory end pieces lined with columnar to pyramidal cells. The interlobular connective tissue reduced with age whereas the other glandular end piece increased. The main excretory duct of the gland was lined by stratified cuboidal epithelium. 
Roy et al. observed simple cuboidal to columnar epithelium with a few basal cells in ram. The prostatic ducts were lined with pseudostratified columnar epithelium which became transitional type at their opening in the urethra.

The pars disseminata lay in the urethral wall surrounded by its own capsule of loose connective tissue in the neonatal group. A layer of skeletal urethral muscle surrounded the gland capsule from outside in all age groups. The parenchyma comprised of cisternae and ducts with a few non-luminated secretory end pieces in the neonates- which became plenty and luminated with age. The ducts were more profusely branched with age ending up into the secretory end pieceswhich were more luminated and less solid as the age advanced. They were initially predominantly mucous type, but later in pubertal and post-pubertal animals' serous component were added by differentiation of non luminated secretory end pieces. Aitken reported numerous compound tubules in the prostate. In the pubertal and post pubertal animals cuboidal/ columnar secretory lining cells were observed in the gland. Their terminal duct was lined by transitional epithelium. This observation was supported by Kundu. Gupta \& Singh reported mostly serous glands with a few mucous acini in pars disseminate of the bucks which also goes in favour of the present observations. Yao \& Eaton (1954) however, observed pseudostratified columnar epithelium lining the pars disseminate of Phillipine goats. Sudhakar et al. (1985) described that the solid and luminated secretory end pieces of pars disseminate remained undifferentiated till 2 years and became differentiated into serous and mucous components after 4 years of age in Murrah buffaloes- this stage can be compared with the pubertal goats $>18$ month age of the present study. The maximum growth of the prostatic parenchyma occurred in the prepubertal animals from birth to 18 months of age after that almost all the parameters grew very slow. This was similar to the observations of Gupta who observed growth in the parenchymatous elements up to 12 month of age in Beetal goats after which it became static up to 24 month age. He further indicated the role of testicular hormones on the growth of the serous acini of the prostate. Maximum and a continuous growth occurred in the capsular components of the gland up to the post pubertal stage, which was in contrast to the observations in the parenchymatous components.

Staining with PAS revealed glycogen containing substances in the parenchymatous components of the corpus prostatae. The reaction was strong in prepubertal and pubertal animals which reduced in older animals. The Alcian blue reaction for AMPS was low in the prepubertal but increased with the differentiation of the mucous acini in the gland. These findings were in line with the text book description (Trautmann \& Fiebiger, 1957; Dellmann \& Wrobel) and others in goat (Gupta \& Singh; Gupta) buffalo (Chandrapal, 1976; Sudhakar et al., 1984) and sheep (Aitken). Tsukise \& Yamada (1987) also investigated certain glycoconjugates in the epithelium of goat prostate.

A diffuse Sudanophilia persisted in all the parenchymatous components throughout the life span of the Gaddi goats in the pars disseminate which was similar to the observations of Banks (1974), Chandrapal, Sudhakar et al. (1984) and Gupta. Gupta \& Singh however, did not find fat in male Beetal goats. A mild to moderate alkaline phosphatase and moderate to intense acid phosphatase activities were recorded in the ducts and acini of the pars disseminata. Pawar et al. (1988) recorded a mild reaction for acid phosphatase and moderate reaction for alkaline phoaphatase in the acini and ducts of the prepubertal goats. In adult animals the reaction was moderate in both the segments of the gland. Chandrapal recorded a weak alkaline phosphatase activity in bulls prostate. The latter author also detected acid phosphatases in the parenchymatous components in all stages of puberty in buffalo. A moderate Bromophenol Blue reaction for protein and strong Feulgen reaction for DNA was evident throughout the gland and more so in the parenchyma and less so in the stromal elements of the prostate in all ages of the animals.

PATHAK, A.; KATIYAR, R. S.; SHARMA, D. N.; FAROOQUI, M. M. \& PRAKASH, A. Estudios anatómicos macroscópicos, histológicos e histoquímicos sobre el desarrollo postnatal de la glándula prostática de la cabra Gaddi. Int. J. Morphol., 30(2):731-739, 2012.

RESUMEN: Se realizó un estudio de la glándula próstatica de la cabra Gaddi, desde el día uno de nacimiento hasta después de los cinco años de edad, divididos grupos prepuberal (1 día a 18 meses de edad), puberal (18 meses a $<5$ años de edad) y postpúberes (más de 5 años de edad). La próstata estaba constituida por un cuerpo prostático, estructura como una banda cercana a la unión de la glándula vesicular con la uretra, y una pars diseminada la cual se extendía en las paredes de la uretra desde su origen hasta el punto de los conductos de la glándula bulbouretral. Microscópicamente, el cuerpo prostático está compuesto por dos masas compactas glandulares situadas una sobre la otra, dorsalmente sobre el origen de la uretra pélvica cubierta por una gruesa cápsula fibro-reticular. La glándula compuesta por piezas terminales (acinos luminal y no luminal) y conductos dispuestos en forma lobulada. El espesor del tejido conectivo inter e intralobulillar disminuyó con el aumento de la edad a expensas del crecimiento del parénquima. Con la edad aumentaron las piezas terminales secretoras luminales, mientras que en las piezas terminales no luminales, disminuyeron en los lóbulos de la glándula. El parénquima glandular era abundante en componentes mucosos a la edad de 6 meses, mientras que los componentes serosos y mucosas se equilibraron a los 12 meses de edad; la mayoría de las piezas finales secretoras se transformaron a tipo serosa. Los conductos excretores que estaban revestidos por epitelio cúbico estratificado en el día uno de las crías, cambió a epitelio de transi- 
ción en los animales prepúberes y púberes. Los elementos glandulares fueron reactivos al PAS y al carmín de Best, mientras que el tejido conectivo intersticial no fue reactivo. Una reacción leve a la fosfatasa alcalina fue evidente en las células del tejido conectivo intersticial, mientras que una reacción fuerte se evidenció en el endotelio. La reacción de BPB para proteína fue de moderada a intensa. Los conductos y acinos eran reactivos al PAS y Alcian Blue. La reacción de glucógeno y el contenido AMPS en la glándula aumentó con la edad. Fue muy intensa en los animales durante la pubertad. La actividad ADN moderada, y de leve a moderada para fosfatasas alcalinas y ácidas en los acinos glandulares y de epitelio ductal reveló glándulas secretoras funcionalmente activas en la pubertad de todos los animales .

PALABRAS ClAVE: Próstata; Postanatal; Corpus prostatae; Pars diseminada; Cabra.

\section{REFERENCES}

Aitken, R. N. A histochemical study of the seminal vesicle of the sheep. J. Anat., 89(4):430-9, 1955.

Ali, H. A.; Moniem, K. A. \& Tingari, M. D. Some histochemical studies on the prostate, urethral and bulbourethral glands of the one-humped camel (Camelus dromedarius). Histochem. J., 8(6):565-78, 1976.

Banks, W. J. Histology and Comparative Organology: A Text-Atlas. Baltimore, Williams \& Wilkins, 1974. pp.239-42.

Barka, T. \& Anderson, P. J. Histochemistry: Theory, Practice and Bibliography. New York, Harper and Row Publisher Inc., 1963.

Chandrapal. Gross histological and histochemical studies on the male genital system of buffalo (Bubalus bubalis). Ph.D. Thesis. Agra University, Agra, 1976.

Davenport, H. A. Histological and histochemical technics. Philadelphia, W. B. Saunders Company, 1960.

Dellman, H. D. \& Wrobel, K. H. Male reproductive system. In: Text book of Veterinary Histology. Dellman, H. D. \& Brown, E. H. (Eds.). Philadelphia, Lea \& Febiger, 1976. pp.306-11.

Eurell, J. A. \& Frappier, B. L. Textbook of Veterinary histology. Ames, Blackwell publishing, 2007.

Gupta, A. N. Correlative Anatomy of the testes, epididymis \& accessory sex glands in goat. Ph. D. Thesis, HAU, Hisar, 1989.

Gupta, A. N. \& Singh, Y. Histological and histochemical studies on the prostate gland of goat. Indian J. Anim. Sci., 52:82-9, 1982.

Hafez, E. S. E. Reproduction in farm animals. 5th ed. Philadelphia, Lea and Febiger, 1987. pp.26-7.
Kundu, P. B. Anatomical studies on the accessory male sex glands (gross and microscopic) of the Indian goat (Jamunapari and cross Jamunapari). Indian J. Anim. Health, 19:151-3,1980.

Luna, L. G. Manual of Histologic Staining Methods of the Armed Forces Institute of Pathology. 3rd ed. New York, McGraw-Hill, 1968. pp.38, 80, 87, 145, 157, 158, 163.

Pawar, H. S.; Saigal, R. P.; Roy, K. S. \& Singh, Y. Histoenzymic studies on prostate gland of goat. Indian J. Anim. Sci., 58:350-2, 1988.

Pearse, A. G. E. Histochemistry Theoretical and Applied. London, Churchill Livingstone, 1968.

Roy, K. S.; Pawar, H. S. \& Saigal, R. P. Histomorphological, histochemical and histoenzymological studies on prostate gland of ram (Ovis aries). Indian J. Anim. Sci., 55(12):983-6, 1985.

Sisson, S. Sisson \& Grossman's The Anatomy of the Domestic Animals. Getty, R. (Ed.). 5th ed. Philadelphia, W. B. Saunders Co., 1975. pp.768-9. Vol. I.

Stallcup, O. T. Enzymatic activity of bovine accessory glands. J. Anim. Sci., 28:145, 1969.

Sudhakar, L. S.; Dhingra, L. D. \& Sharma, D. N. Histomorphological studies on the body of the prostate gland (Corpus prostatae) of Murrah buffalo during postnatal development. J. Res. Haryana Agric. Univ., 14(3):273-81, 1984.

Sudhakar, L. S.; Dhingra, L. D. \& Sharma, D. N. Histomorphological studies on pars disseminata of the prostate gland of Murrah buffalo during postnatal development. Indian J. Anim. Sci., 55(10):847-53, 1985.

Trautmann, A. \& Fiebiger, J. Fundamentals of histology of domestic animals. Ithaca, Comstock Publishing Associates, 1957. pp.26972.

Tsukise, A. \& Yamada, K. Secretory glycoconjugates in the epithelium of the goat prostate. Histochem. J., 19(6-7):345-50, 1987.

Yao, T. S. \& Eaton, O. N. Postnatal growth and histological development of reproductive organs in male goats. Am. J. Anat., 95(3):401-31, 1954

\section{Correspondence to:}

Dr. Archana Pathak

Associate Professor,

Deptt. of Anatomy,

COVSc. \& A.H.

Pt. Deen Dayal Upadhyaya Veterinary University-Mathura; INDIA

Email:- pathak_arcvik@yahoo.com

Received:11-12-2011

Accepted:03-02-2012 